VERSITA

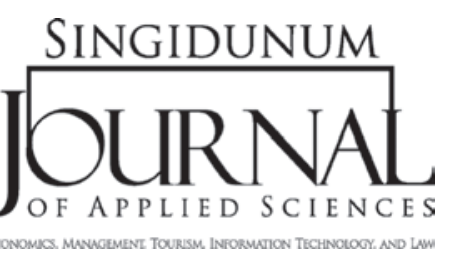

SJAS 2014, 11 (1): 34-42

ISSN 2217-8090

UDK: 005.591.6; 339.137

DOI: $10.5937 /$ sjas $11-5015$

Original paper/Originalni naučni rad

\title{
THE IMPORTANCE OF MARKETING INNOVATION IN NEW ECONOMY
}

\author{
Dejan Ilić, ${ }^{1, *}$, Slavica Ostojić ${ }^{2}$, Nemanja Damnjanović ${ }^{2}$ \\ ${ }^{1}$ Union University - Nikola Tesla, Faculty for Strategic and Operational Management \\ 29 Staro Sajmiste Street, Belgrade, Serbia \\ ${ }^{2}$ Faculty of Business Economics and Entrepreneurship \\ 8 Mitropolita Petra Street, Belgrade, Serbia
}

\begin{abstract}
:
The new economy is greatly determined by the globalization process, radical and frequent changes, as well as the growing importance of knowledge application through the successful implementation of innovation. These determinants directly affect the fact that sustainable competitive advantage primarily reaches organizations that have developed the ability to improve the level of efficiency and effectiveness with the constant development of the total innovation performance. In the new economy, organizations that have the ability to develop and adopt the invention in a short period of time and profitably apply it in all areas of business reach competitive advantage over the competition in time. The growing importance of innovation in function of achieving a sustainable competitive advantage determined a brand new concept and innovation classification. Nowadays, the term innovation means not only a significant improvement in process and product technology, but it refers more to the innovation process in the field of human resources, especially in marketing management. For the above mentioned reasons, the paper pays special attention to the marketing innovation analysis and the increasingly significant impact it has on the process of achieving sustainable competitive advantage.
\end{abstract}

\author{
Key words: \\ innovation, \\ marketing innovation, \\ sustainable development, \\ sustainable competitive advantage, \\ social networks.
}

\section{INTRODUCTION}

Productivity and competitiveness are the factors that stimulate high economic growth without inflation, but innovation is the factor which runs the new economy (Zjalić, 2007, pp. 155-182). The new economy is mainly characterized by the intensive use of knowledge, rapid changes and hyper-competition.

Hyper-competition is a condition in which the competitors are emerging from the expected and unexpected directions with an aggressive approach, thus rapidly changing relationships and achieving competitive advantage (Pearlson and Shunders, 2010).
The speed at which things are changing in the contemporary environment is an increasingly important parameter in achieving competitiveness. That is why the well-known author in the field of management, Adižes (2009), emphasizes that the change is not new, but it is new that the speed of change is increasing. In the future the only constants that will be strongly dominant are change and knowledge and they will provide the most appropriate solutions. The speed of change and development of hyper-competition on the basis of the globalization process have caused the transition from an economy based on the industrial revolution to the new economy (Ilić, 2004, pp. 99126) based on knowledge and innovation. 


\section{SUSTAINABLE DEVELOPMENT AND SUSTAINABLE COMPETITIVE ADVANTAGE}

The sustainability is becoming one of the fundamental questions that should be the starting point of every human activity in specific modern economy. Basically, the concept of sustainability is integrating previously acquired experience, current business practices and vision for the future (Ilić et al., 2012, pp. 264-270). Sustainability as a strategic objective involves optimization of many interactions between nature, society and economy but in accordance with the Ecology criteria (Pokrajac, 2003, pp. 17-29). In all industries the concept of sustainable development integrates and coordinates the economic, scientific and technological processes, as well as different ways of natural resources exploitation.

These findings further imply that only the successful implementation of innovation with a constant focus on improving profitability growth with environmental protection can guarantee sustainable development of organizations and the entire nations. Organization reaches a sustainable competitive advantage on the basis of sustainable development by strengthening the organizational culture that promotes innovation with open technology transfer and management approach of total customer satisfaction. The term total customer satisfaction is defined as the ability of the organization to deliver more value for the consumer in order to achieve a higher degree of loyalty. Total customer satisfaction represents a set of factors that differentiate the organization from its competitors and give it a unique position on the market (Porter, 2007). Innovation in the function of achieving total customer satisfaction sets a company apart from the competitor with respect to critical success factors (Kettunen et al., 2007).

Sustainable competitive advantage is a relationship that involves the following: conducting business activity in more efficient, effective, and innovative way with a higher differentiation degree in order to deliver more value to the consumer compared to the reference competition (Ilić, 2012, pp. 13-35). Organizations tend to develop dynamic system identification and introduce innovation, because in this way they increase their own chances of changing the nature of competition, achieving a distinctive competitive advantage over direct competitors (Sawhney et al., 2006, p. 81). The improvement of the overall innovation of the organization's performance is of crucial importance for higher differentiation and total customer satisfaction.

\section{MARKETING INNOVATION AND THEIR IMPORTANCE}

Innovation in the broadest sense is practical application of new ideas (Millson and Wilemon, 2008). With this broad definition it is necessary to make a distinction between the concept of creativity and innovation. Creativity refers to the ability to generate new ideas, while innovation refers to the activity which represents the process of implementation of new ideas and creation of new things (Stošić, 2007, p. 3).

In addition to the drastic improvement of products and services, innovation is also related to the process that involves the collection and processing of ideas and their realization (Stošić, 2007, pp. 3-20). Innovation represents the implementation of new or significantly improved products, services, processes, new marketing method, or a new organizational method in business practices in the internal or external business organizations (OECD, 2005, pp. 9-25). All of the above applies to products, processes, methods that the organization developed for the first time and which are adapted or adopted by other organizations (OECD, 2005, pp. 9-25). A wellknown author in the field of innovation management, Trott, (2008, p. 15) defines innovation as a set of activities related to the process of gathering ideas, technological development, marketing, production of new or improved products and production processes and equipment. In the joint edition that deals with innovation, OECD and Eurostat point out that until recently innovation included improvement in the production processes and new product development, while today it includes innovation in terms of organization and marketing innovation (OECD, 2005, pp. 9-25).

In the modern economy organizations that understand the new rules of marketing develop relationships directly with consumers (Scott, 2013, p. 15). The main objective of marketing innovation is to improve the identification process and profitable satisfaction of customer needs. By implementation of new marketing methods and activities organization aims to establish a closer relationship with customers and brings them into a situation when customers become promoters of the organization - a condition in which consumers are loyal to the organization and recommend it to their reference groups (Kotler and Keller, 2006, pp. 9-95). Despite the aforementioned, other objectives of marketing innovation are: penetration 
into new markets i.e. improving the visibility level and presence of the product in the market as well as achieving large scale and sales frequency.

The basic marketing tools, i.e. basic marketing mix elements (so-called the $4 \mathrm{P}$ - product, price, place, and promotion) are appropriate combination of components through which organizations achieve their own marketing objectives and reach sustainable competitive advantage (Kotler, 2000).

Marketing innovation is based on the promotion of the four instruments that are inter-related and focused on meeting the consumer needs by achieving a sustainable competitive advantage (Ferrell and Hartline, 2011, pp. 18-19). So, marketing innovation involves the use of completely new marketing strategies, marketing concepts or new marketing methods that have never been applied in the organization. They are based on the combination of the following elements (Stošić, 2007, pp. 3-20):

- Significant product design improvements (changes in form and packaging),

- Implementation of new pricing strategies,

- Implementation of an entirely new retail concept (introduction of completely new distribution channels),

- Implementation of an entirely new promotion concept (advertising on social networks).

\section{Product design innovation}

Marketing innovation in terms of changes in product design includes significant changes in the shape and packaging as integral parts of the marketing concept (Kotler and Keller, 2006). More specifically, marketing innovation in terms of product design includes significant changes in terms of packaging form or product style without affecting the functioning and usage characteristics of the product (Stošić, 2007, pp. 3-20). Marketing innovation of the design included significant changes of the following elements that an organization first applied with regard to all existing products (Stošić, 2007, pp. 3-20): the implementation of a completely new design in order to achieve dramatically different and special appearance; significant changes in appearance, shape, color and style in order to obtain a completely new, differentiated, distinctive look/appearance of the product. Marketing innovation in terms of product packaging would include significant changes in the following elements (Trott, 2008, pp. 424-438): significant improvement of the packaging protec- tive function, materials, reliability and satisfaction when opening and using packaging, significant improvement of packaging identification that includes additional information on the use, promotional/ sales actions, significant improvement of the package shape and size.

\section{Innovation of pricing strategy}

According to the economic theory, price is a balance between supply and demand. That is the reason why the pricing strategy uses the turning profitability point as the basis of innovation. So, for all of these examples, the rule is that lower limit of price formation makes the turning point (point of return). The price level above the turning point is formed on a variable manner influenced by the demand level.

Marketing innovation in pricing involves the use of a completely new pricing strategy that the organization applies for the first time in its products and services in a particular market (OECD, 2005, pp. 9-25). An example of marketing innovation in pricing is the application of a new variable price calculation based exclusively on demand factors for a particular product or service. For example, innovation is the application of the method in the organization for the first time and involves the approval of discounts in the store for consumers that have certain credit or preferential cards issued by organizations. Discounts may be financial in the form of lower prices or physical when a consumer gets a greater amount at the same price or receives a completely new product as a bonus. One more example is given as a marketing innovation. Marketing innovation may be the introduction of a new interactive method of "online" pricing on the organization website. "Online" service allows the consumer to choose the desired set of products on the organization's website and receive a price that is formed exclusively on the basis of individually selected product characteristics (OECD, 2005, pp. 9-25).

\section{Innovation of sales channels}

The introduction of new sales channels and marketing innovation include implementation of new marketing methods that have never been applied in the organization. The introduction of new sales channels includes the implementation of entirely new marketing methods and selling products/services to customers. The introduction of new sales channels is marketing innovation while improving logistics 
(transport, storage and handling of the product) is not represented. The examples of marketing innovation related to the introduction of new distribution channels are: first, the introduction of licensing products, franchise, exclusive sales, and direct sales (the introduction of their own sales network i.e. their own chain of retail centers or development of direct trade via the Internet).

\section{Innovation of promotional methods}

The basis of all promotional activity is a communication process. For this reason, the concept of promotion is a mechanism for communication and exchange of information between consumers and organizations. The task of promotion is to inform, remind and persuade consumers to act, purchase and consume certain products (Trott, 2008, pp. 351-385). Marketing innovation is the implementation of a new marketing method to promote products or services of a particular organization. Examples of brand new marketing promotion method are:

- The introduction of an entirely new kind of media - promoting products/services in a feature film, a TV show or on the Internet (the first introduction of the web site or promotion via internet social networks like Facebook, MySpace, Twitter;

- The introduction of completely new techniques, such as the use of celebrities in order to improve the promotion of products/ services;

- Significant improvement or modification brand-development and implementation of a completely new or significantly improved symbol that is drastically different from the current visualization (OECD, 2005, pp. 9-25).

The main objective of marketing innovation in terms of branding is product positioning in the new market or creating a new image (introducing a brand new personalized presentation of products/services based on the specific requirements of individual customers).

\section{SOCIAL NETWORKS AND MARKETING INNOVATION RELATIONSHIP}

In the interactive era of the twenty-first century organizations are strategizing how to gain sustainable competitive advantage from the information they gather about customers (Peppers and Rogers, 2011, p. 4). This is the reason why organizations must manage their customer relationships effectively in order to remain competitive (Peppers and Rogers, 2011, p. 3).

There are transactional and relational marketing in the marketing literature (Ferrell and Hartline, 2011, p. 24). In transactional marketing key element is marketing mix. In relationship marketing, the relations with customers and business partners are of key importance (Rakić and Rakić, 2008, pp. 255-259). Relationship marketing is based on good communication (Feiertag, 1997, p. 18). Relationship marketing consists of "invisible network", "focused message" and approach such as "listen and serve" (Levinson and McLaughlin, 2005, pp. 8-12). Establishing and maintaining relationships with business partners affect the effectiveness. Communication with customers enables the production of "real" products according to the customer needs and desires. Communication with suppliers enables the purchase of "real" inputs. Communication with distributors enables delivering products to consumers when needed. To establish and maintain communication, it is necessary to apply information technology. Another significant change is changing the customer role (Rakić and Rakić, 2003, pp. 95-104). It is often unproductive to allocate big sums of money to the forced media campaigns. During the crisis shopping habits and consumption are changing. The job loss and lower incomes are examples of market paralysis convergence and bad debts. Only powerful companies (large market players) directed funds to TV commercials trying to bring their brands to the customer's living room. However, the impressive advertising costs of the strongest national media (RTS, Pink, B92, etc.) can smartly reduce and redirect resources to higher visibility on the shelves.

It is desirable to direct part of the "marketing" money to the gathering places of their consumers - such as the Internet and social networks. It is important to achieve long-term brand positioning (Manić, et al., 2009, pp. 205-214). Thanks to the Internet, consumers are more connected and they are more active and more demanding. Technological advancements have enabled organizations to manage customer relationship more efficiently, but also empowered customers to "be informed and demand much more" (Peppers and Rogers, 2011, p. 3). Longterm relationships will not materialize unless these relationships create value for each participant. This is especially true for customers faced with many different alternatives among firms. It further directs the organization to engage customers in the process of defining a single common value concept (Ferrell and Hartline, 2011, pp. 23-24). 
In a competitive environment organizations cannot rely only on the internal environment of research and development. It is necessary to engage partners outside the company in accordance with the "connect and develop" model of innovation (Rakić and Rakić, 2007a, pp. 329-338).

Marketing activity of the company must be harmonized to produce the best effects. Each form of communication has its own specific features including communication through social networks, which requires the creation of a special message for social networks. All these marketing innovations are of great importance for raising the total performance of the organization. However, in modern digital society, marketing innovations related to the exploitation of the Internet increasingly gain in importance. They are set aside in a special category called Internet marketing. In recent years Internet marketing and social media have become a "new hybrid component of integrated marketing communications that allow organizations to establish strong relationships with their consumers (Mangold and Faulds, 2009, pp. 357-360). In today's economy, Internet marketing and especially the use of social networks for achieving more successful advertising, promotion and closer contact with consumers, have become increasingly significant. Internet marketing and online social network have become increasingly significant, because, "we are in the era of social marketing” (Reed, 2012, p. 3). Examples of the importance of advertising on social networks are shown in the following data: in July $2009 \mathrm{Fa}-$ cebook had 350 million users, MySpace 125 million and Twitter 75 million (Treadaway and Smith, 2010). Nowadays, Facebook has over 1.19 billion monthly active users (Facebook, 2013).

This is the reason why the organization within the marketing budgets for advertising in 2014 allocated more resources than the previous year: $4.2 \%$ for TV, $5.5 \%$ more than in the past for billboards and even $27 \%$ for Internet advertising (Oglašivači najviše novca izdvajaju za TV, 2013). One of the most important aspects of marketing innovation is the promotion of organization and organizational products and services through social networks as Facebook, MySpace; creativity works-sharing sites as YouTube; collaborative websites like Wikipedia, and micro blogging sites as Twitter (Mangold and Faulds, 2009, pp. 357-360).

Marketing on the social network "is not about you getting your story out; it's about your customers; it's about being more transparent, earning trust, and building credibility" (Webber, 2009, p. 36). Social networks are the basis of the use of guerilla marketing, which focuses on achieving maximum results with minimum investment. Guerrilla marketing assumes innovation and creativity of those who deal with it or those who wish to apply (Levinson, 1989). When properly executed, advertising on social network can be a powerful guerrilla weapon (Levinson and McLaughlin, 2005, p. 108). Guerrilla Facebook Marketing weapons refer to Facebookspecific features, tools and resources that guerrillas can use to further their marketing plans (Levinson and Kelvin, 2013, p. 129). Facebook offers space for unconventional type of marketing without investing any money. Profile is created in a way to attract more "friends". It is easy to express a desire for a particular brand, product or company which is beeing advertised. An example of guerrilla marketing is an American pizza chain Papa John's. Thanks to a guerrilla campaign on Facebook, they gathered 148,000 fans. The campaign was designed so as that each new fan gets a free pizza delivered to their home (Stanojević, 2011, p. 168).

\section{MARKETING INNOVATION IN THE REPUBLIC OF SERBIA}

In order to perceive the situation and propose corrective actions regarding the marketing innovation, this paper analyzes the results of several different studies. The studies were about innovative activities of organizations operating in the Republic of Serbia. First results included in the analysis were taken from a study conducted in 2008-2010, (Republički zavod za statistiku, 2011, pp. 1-6). The sample of 3982 organizations included active small and medium enterprises (over 10 employees) and 492 large business systems. The results of the research show that the most common activities refer to innovation of the organization with $32.5 \%$, followed by marketing innovation with $29.3 \%$, and the least common one is product/service innovation with $27.4 \%$. Percentage of organizations that did not innovate was even $52.1 \%$. There were high rates of organizations in the time interval 2008-2010 that didn't innovate (Republički zavod za statistiku, 2011, pp. 1-6). The figure shows a negative balance in terms of innovation for the majority of organizations (operating) in the Republic of Serbia.

The Ministry of Finance and Economy announced that the Republic of Serbia accounts for $99.8 \%$ of total 
enterprises in the entrepreneurial sector (Izveštaj o malim i srednjim preduzećima i preduzetništvu u 2011, 2012, p. 15). Further analysis should incorporate the results of another study whose aim was to analyze current situation and possibilities for improvement of small and medium enterprises (SMEs). Research on small and medium enterprises (SMEs) was conducted by the Statistical Office of the Republic of Serbia. The study was published in the report on small and medium enterprises and entrepreneurship (Izveštaj o malim i srednjim preduzećima i preduzetništvu u 2011, 2012, pp. 15-66), and the results refer to the year 2010. The survey was conducted on a sample of 3,500 organizations including micro enterprises (1-10 employees) and entrepreneurs (regardless of the number of employees). Selected results of the survey were as follows: the effects of innovation are conducted in $54 \%$ of cases referred to the saving of raw materials and energy, $46 \%$ reduction in labor costs and only $22 \%$ have some form of safeguard intellectual property. The total number of respondents who protect any kind of intellectual property is $62 \%$ regarding the private brand, $21 \%$ of the design and only $8 \%$ of patents. When it comes to innovation, marketing results were as follows: packaging design changes or product/service $11.65 \%$, new marketing methods to promote products $15.31 \%$, new or changed methods of distribution $8.87 \%$, the new pricing method $20.14 \%$. The analysis of the results obtained from this research show that small and medium enterprises (SMEs) are primarily focused on the development of innovation with their own forces, and then in cooperation with other organizations and institutions. The effects of the introduced innovations in SMEs are mostly related to the improvement of product quality $28.82 \%$, increase of the range of products and services $23.64 \%$, application of new pricing methods $20.14 \%$, and the least significantly related to the reduction in costs per unit and improvement of internal and external communication - 5.31\%.

The next study involved the analysis of the qualitative research that was conducted in the period October-December 2011 in the territory of the Republic of Serbia (Ilić, 2012, pp. 208-238).

The above qualitative research refers to the evaluation of the expert awareness level of various profiles of the impact of innovation in improving the competitive advantage of organizations. The method used in the interview includes qualitative form of research that is based on the discussion - a moderator and only one subject.
This type of research is conducted to provide a deeper insight in the state that is currently characteristic for the organization in the Republic of Serbia regarding innovation and competitive advantage, but also the level at which innovation is actually implemented in organizations. Respondents who participated in this research represent a deliberate pattern or "experts sample". That means that the respondents were not selected randomly, but based on carefully defined criteria and based on their knowledge and expertise in the business success of the organizations in which they work. The results of this qualitative study show that, unfortunately, not enough effort and financial resources were invested in successful implementation of innovations in all fields. This particularly refers to the marketing innovation area despite the previously mentioned quantitative results that the level of marketing innovation in the Republic of Serbia of 29.3\% exceeds the level of marketing innovation in the EU of $26.6 \%$ (European Commission and Statistical Office of the European Communities, 2011, pp. 79-95). According to the opinion of respondents in the conducted qualitative research, higher level of investment in marketing innovation is the result of confusion that most of the respondents have regarding the classification of unfounded minor stylistic changes in web sites and seasonal price changes and/or seasonal promotions, they classify them as marketing innovations, but these are not marketing inovations. However, there are positive examples of marketing innovation in the Republic of Serbia. One of them is marketing agency McCann Erickson. In 2010-2011 McCann Erickson improved the quality of services to clients in the fields of advertising, especially in the field of advertising on social network such as Facebook (Ilić, 2012, pp. 208-242). In support of the above conclusion it also lists data released by the Statistical Office of the Republic of Serbia and according to them in $201297.7 \%$ organizations use the Internet for business, while $47.5 \%$ of the Serbian population use the Internet daily (Republički zavod za statistiku, 2013). As for the number of Facebook users, according to research results published on the website Adriatalk.com, Serbia is ranked as number one in the region and the 18th in Europe (Banković and Gijić, 2010, pp. 390-395). The results of this study show that the total number of Facebook users in Europe exceeded 114 million. This trend further emphasizes the importance of promoting the organization through social networks and other forms of marketing innovation in the process of strengthening relationships with consumers. 


\section{CONCLUSION}

Companies can gain sustainable competitive advantage through differentiation based on creating a single common value concept for consumers and contributing to sustainable development. Sustainable development is an important aspect of marketing. Besides economic viability, company must achieve the goals of environmental sustainability. The companies preferred in the contemporary economic conditions are the ones managing to link innovation and marketing successfully. Innovation can be seen as an asset of the company, which is directly related to the feedback of marketing. Innovation is the main driver of competitiveness. In today's digital era it is important to make maximum use of new communication technologies and the Internet - especially in marketing and sales.

The real challenges lie ahead of the company management: which marketing tools to retain and amplify, which ones to leave out and which sales strategy is the most effective. Nowadays, it is not just enough to know what consumers are looking for. Those who are familiar with market trends can predict which products consumers will put emphasis on. The changes have become more frequent and more distinct. The changes have become "the law of the market". However, the biggest threat is the increasing speed of changes.

The change was a crucial factor for professionals in marketing and sales. Of course, sometimes it is best to maintain market position and retain market share. When the crisis waves begin to lose strength, it is ideal to have a good start in the competitive arena. You need to think of and plan the time after the crisis.

\section{REFERENCES}

Adižes, I. (2009). Kako upravljati u vreme krize: I kako je pre svega izbeći. Novi Sad: Asee. (in Serbian).

Banković, D., \& Gijić, N. (2010). Application of WEB 2.0 technologies in business. In: Application of new technologies in management, 2nd International Conference ANTiM 2010 (pp. 390-395). Tara: Faculty for Education of the Executives of the University of Business Academy.

European Commission, \& Statistical Office of the European Communities. (2008). Science, technology and innovation in Europe. Luxembourg: Office for Official Publications of the European Communities.
Facebook. (2014). Key facts. Retrieved October 5, 2013, from http://newsroom.fb.com/Key-Facts.

Feiertag, H. (1997). Relationship selling works only when practiced. Hotel \& Motel Management, 212(6), 18.

Ferrell, O.C., \& Hartline, M.D. (2011). Marketing strategy (5th ed.). Mason, OH: South-Western Cengage Learning.

Ilić, B.B. (2004). Tranzicija industrijske (tradicionalne) u novu (informatičku) ekonomiju. Ekonomski anali, 49(162), 99-26. (in Serbian). doi: 10.2298/ EKA0462099I.

Ilić, D. (2012). Menadžment inovacija u funkciji stvaranja i održavanja konkurentne prednosti organizacija. Novi Sad: Alfa University, FORKUP. (in Serbian).

Ilić, D., Veljković, D., \& Ostojić, S. (2012). Sustainable development of organization via production of alternative fuel. In: Application of new technologies in management, 3rd International Conference ANTiM 2012 (pp. 264-270). Beograd: Faculty for Education of the Executives, Alfa University.

Izveštaj o malim i srednjim preduzećima i preduzetništvu u 2011. (2012). Beograd: Ministarstvo finansija i privrede; Ministarstvo regionalnog razvoja i lokalne samouprave; Nacionalna agencija za regionalni razvoj (pp. 15-66). (In Serbian).

Kettunen, J., Ilomaki, K., \& Kalliokoski, P. (2007). Making sense of innovation management. Helsinki: The Federation of Finnish Technology Industries and Teknologiainfo Teknova Oy.

Kotler, P. (2000). Marketing management. New Jersey: Prentice Hall.

Kotler, P., \& Keller, K. (2006). Marketing management (12th ed.). New Jersey: Prentice Hall.

Levinson, J.C. (1989). Guerrilla marketing attack: New strategies, tactics, and weapons for winning big profits for your small business. Boston: Houghton Mifflin.

Levinson, J.C., \& Lim, K. (2013). Guerrilla Facebook marketing: 25 target specific weapons to boost your social media marketing. New York: Guerilla Marketing Press.

Levinson, J.C., \& McLaughlin, M.W. (2005). Guerrilla marketing for consultants: Breakthrough tactics for winning profitable clients. Hoboken, N.J: Wiley.

Mangold, W.G., \& Faulds, D.J. (2009). Social media: The new hybrid element of the promotion mix. Business Horizons, 52(4), 357-360.

Manić, M., Riznić, D., \& Ostojić, S. (2009). Inovativne strategije marketinga i prodaje u uslovima globalne krize. In: Zbornik radova: Suočavanje sa globalnom ekonomskom krizom od strane kompanija i ekonomije, Sedmi Međunarodni naučni skup Megatrend univerzitet (pp. 205-214). Beograd: Megatrend univerzitet. (in Serbian). 
Millson, M.R., \& Wilemon, D.L. (2008). The strategy of managing innovation and technology. Upper Saddle River, N.J: Pearson Prentice Hall.

Oglašivači najviše novca izdvajaju za TV. (2013). Marketing mreža. Retrieved October 21, 2013, from http://marketingmreza.rs/oglasivaci-najvise-novcadaju-za-televiziju. (in Serbian).

Organisation for Economic Co-operation and Development, \& Statistical Office of the European Communities. (2005). Oslo manual: Guidelines for collecting and interpreting innovation data (3rd ed.). Paris: OECD Pub.

Pearlson, K., \& Saunders, C.S. (2010). Managing and using information systems: A strategic approach (4th ed.). Hoboken, N.J: Wiley.

Peppers, D., \& Rogers, M. (2011). Managing customer relationships: A strategic framework (2nd ed.). Hoboken, N.J: Wiley.

Pokrajac, S. (2003). Održivi razvoj i moderna tehnologija kao ekološka raskršća savremene civilizacije. Beograd: Megatrend univerzitet. (in Serbian).

Porter, M.E. (2007). Konkurentska prednost: Ostvarivanje i očuvanje vrhunskih poslovnih rezultata. Novi Sad: Asee. (in Serbian).

Rakić, B., \& Rakić, M. (2003). Radikalne promene: Primena marketinga u organizacijama i privredi u procesu globalizacije. In: Zbornik radova: Medunarodni naučni skup Radikalne promene u preduzećima $i$ privredi u uslovima globalizacije, 28. novembar 2003. Beograd: Megatrend univerzitet primenjenih nauka. (in Serbian).

Rakić, B., \& Rakić, M. (2007). Changes in contemporary marketing in the conditions of globalization. In: Management and marketing under globalization: proceedings, International scientific conference contemporary challenges of theory and practice in economics (pp. 329-338). Belgrade: Faculty of Economics of the University of Belgrade, Publishing Centre.

Rakić, B., \& Rakić, M. (2008). Marketing i inovacije u funkciji razvoja organizacija i privrede. In: Razvojne strategije preduzeća i privrede: zbornik radova, Šesti međunarodni naučni skup, 28. novembar 2008 (pp. 255-259). Beograd: Megatrend univerzitet. (in Serbian).
Reed, J. (2012). Get up to speed with online marketing: How to use websites, blogs, social networking and much more. Upper Saddle River, N.J: FT Press.

Republički zavod za statistiku. (2011). Indikatori inovativnih aktivnosti u Republici Srbiji, 2008-2010. Retrieved October 3, 2012, from http://webrzs.stat. gov.rs/WebSite/repository/documents/00/00/55/83/ IA01_2010_srb.pdf. (in Serbian).

Republički zavod za statistiku. (2013). Upotreba informaciono-komunikacionih tehnologija u Republici Srbiji, 2013. Retrieved December 9, 2013, from http://webrzs.stat.gov.rs/WebSite/repository/documents/00/01/14/03/PressICT2013.pdf (in Serbian).

Sawhney, M., Wolcott, R., \& Arroniz, I. (2006). The 12 different ways for companies to innovate. MIT Sloan Management Review, 47(3), 75-81.

Scott, D.M. (2013). The new rules of marketing \& $P R$ : How to use social media, online video, mobile applications, blogs, news releases, and viral marketing to reach buyers directly (4th ed.). Hoboken, N.J: John Wiley \& Sons.

Stanojević, M. (2011). Marketing na društvenim mrežama. MEDIANALI, 5(10), 165-180. (in Serbian).

Stošić, B. (2007). Menadžment inovacija: Ekspertni sistemi, modeli i metode. Beograd: Fakultet organizacionih nauka. (in Serbian).

Treadaway, C., \& Smith, M. (2010). Facebook marketing: An hour a day. Indianapolis: Wiley Pub.

Trott, P. (2008). Innovation management and new product development. Harlow, England: Financial Times/ Prentice Hall.

Webber, L. (2009). Marketing to the social web: How digital customer communities build your business. Hoboken, N.J: Wiley.

Zjalić, Lj. (2007). Inovativnost - nezaobilazan činilac razvoja. Medunarodni problemi, 59(1), 155-182. (in Serbian). doi: 10.2298/MEDJP0701155Z. 


\section{ZNAČAJ MARKETING INOVACIJA U SAVREMENOJ EKONOMIJI}

\section{Rezime:}

Savremena ekonomija je u najvećoj meri, determinisana procesom globalizacije, radikalnim i frekventnim promenama kao i rastućim značajom primene znanja kroz uspešno implementiranje inovacija. Navedene determinante direktno utiču na činjenicu da održivu konkurentnu prednost prvenstveno dostižu organizacije koje su razvile sposobnost unapređenja nivoa efikasnosti i efektivnosti uz neprestani razvoj ukupnih inovacionih performansi. U savremenoj ekonomiji, organizacije koje su razvile sposobnost da u što kraćem vremenskom intervalu usvoje invencije i na profitabilan način ih primene u svim oblastima poslovanja, dostižu konkurentnu prednost u odnosu na referentnu konkurenciju tokom vremena. Rastući značaj inovacija u funkciji dostizanja održive konkurentne prednosti je uslovio i sasvim novi pristup pojmu i novu klasifikaciju inovacija. Danas se pod pojmom inovacija ne podrazumeva isključivo proces značajnog unapređenja proizvoda i tehnologije, već se pojam sve više odnosi na proces inoviranja u oblasti upravljanja ljudskim resursima a naročito u oblasti marketing menadžmenta. Iz navedenih razloga, u radu je posebna pažnja posvećena upravo analizi marketing inovacija i sve značajnijem uticaju koji imaju na proces dostizanja održive konkurentne prednosti.

\section{Ključne reči:}

inovacije,

marketing inovacije,

održivi razvoj,

održiva konkurentna prednost, društvene mreže.

Received: November 29th, 2013.

Correction: December 25th, 2013.

Accepted: February 21st, 2014. 